\title{
Drama Education Differences Between China and Western Countries
}

\author{
Tian Zhou ${ }^{1}$ \\ ${ }^{1}$ Yunnan Performance Company, Kunming, China \\ Correspondence: Tian Zhou, Yunnan Performance Company, Kunming, Yunnan, China.
}

Received: September 1, 2019

doi:10.20849/aes.v4i2.657
Accepted: September 24, 2019 Online Published: October 9, 2019

URL: https://doi.org/10.20849/aes.v4i2.657

\begin{abstract}
There are overall differences between the education policies and system between the Chinese and western education systems. These differences are brought up by the differences in government policies, the existing student's and orientation system, the country's population and school size, and community attitudes towards the country's education system. By contrast, the education policies in western cultures are designed to prepare students to be more successful people in society by gaining enough educational skills and developing a strong friendship. There are several ways in which the Chinese education system completely varies with the western education system. Western countries focus on adopting varieties of learning methods in achieving a democratic government. For the Chinese, there is the management of the massive population, which is managed by a different mode of government. This paper tries to explain the differences between drama education in China and the Western cultures.
\end{abstract}

Keywords: education policy, education system, drama education, China, western culture

There are overall differences between the education policies and system between the Chinese and western education systems. These differences are brought up by the differences in government policies, the existing student's and orientation system, the country's population and school size, and community attitudes towards the country's education system (Youju, Li \& Hazel, 2014). The education policies in western cultures are designed to prepare students to be more successful people in society by gaining enough educational skills and developing a strong friendship (Cheng, 2014). It gets them in a position where they can go after school and prepare themselves for gainful employment. When compared to China's education system, which is based on competition and desperation, several differences emerge. This paper explains the differences between drama education in China and the Western cultures.

The Chinese government controls the Chinese education system. The government tries to ensure they cater for both the children for wealthy parents and the families for the little people in the country (Yongtao, 2015, pp. 48). There is a high demand for high-tech mathematics, science training, and English medium education than any other type of knowledge like physical education and ideology. There are several ways in which the Chinese education system completely varies with the western education system. Western countries focus on adopting varieties of learning methods in achieving a democratic government. A system that gives all the individuals a voice. For the Chinese, there is the management of the massive population, which is managed by a different mode of government (Wickman, 2019, pp. 134).

Significant assumptions which the Chinese students have about education are; to excel to standout in the crowd and possibly be among the successful people in the country. Different government policies like the one-child policy in China makes the Chinese children have the responsibility of being their parents and grandparents hope for the future. Another major factor which differentiates the Chinese education system from others is the intense competition for employment where several people graduate, but there are fewer opportunities to being employed (Downing, June \& Paul, 2012). Most of the Chinese parents are currently supporting the importance of learning English so that their children can have better chances of prospering in life. In contrary, this is different from the western education system where children are taught to gain skills which will help them to solve various problems in life. It is majorly not based on being prosperous in life.

\section{The Simple Introduction to American and Chinese Education System}

China highly values education from the ancient times, which began with the establishment of the Civil education system which aimed at selecting officials in rigour and fairway. This kind of system was proved to be active, 
and this kind of education system had different levels of examination done at county, provincial, and national levels. This type of analysis majorly involved writing essay tests by referring to arguments from the Four Books and Five Classics. Another part of the basics of this education system entails good calligraphy and proper writing styles. Later, there was a selection of the winner by the Emperor, and a few runners up were also chosen based on the results from the examination (Youju, Li \& Hazel, 2014). Those chosen gained employment into different posts of government official depending on their findings.

Some of the consequences of this historic education system, based on exams and other credentials include underpinning the belief that education effort is of importance than the innate ability. The culture of hard work and tolerance of hardship was a significant effect of civic education.

The American education system has remarkable democratization and expansion of the higher education system (Ding, 2018, pp. 56). The finding supports that during the 1990s, only $4 \%$ graduated from high school while currently the population of students who are graduating stands at $75 \%$, which is almost all the population (Downing, June \& Paul, 2012). According to the New York Times magazine, there is a report that democratization of higher education is one of the significant achievement America has made since world war 11. In today's education system, many ethnic women and diverse minorities are currently undergoing civic education (Wickman, 2019, pp. 134).

In China, the education system comprises of three levels, which are primary, secondary, and post-secondary education. The fundamental level in China is what is written of elementary school while secondary education is split into lower and upper levels. The education system is 6-3-3. In the united states which use the western system of education, the first and the eighth years are generally labelled by the years. The high school education and colleges sare arranged as a freshman.

China's education system has undergone continuous changes and reforms intending to promote quality education as the central core. The government of China regularly adjust its policies to make the system fit the country's social and economic developments. Just like the western countries, the primary aim of expanding and changing education policies is to improve the quality of education. The local Chinese government usually manages its education system by using the Five-Year Plans for social and economic development.

In China, students must always pay attention to their homework and ensure to review the knowledge learned in class when spending their leisure time (Yongtao, 2015, pp. 48). While in America, this is very different since most of the learning is taken care of by the teachers. Also, Chinese high school students have no choice in choosing subjects, which is very different from the education system in the western cultures.

\section{School Size and Individual Care}

With China's more extensive and overwhelming population, there are more prominent schools with large students' community in classes. Most of the students in China attend political pieces of training while in western education, each child is valued and looked after with the policy of 'No child left behind' in the United States (Cheng, 2014). Disadvantaged students are treated with much care since diversity exists in classrooms. Implying that social need student no longer has separate classes from other regular students. Also, students testing done through standardized examinations and other school-based programs. It is also done to determine if the student has achieved the required learning outcome (Finn, 2011, pp. 118).

In China, there is a comfortable and relaxed learning environment with hardly individualized exams. It seems to be useful in this kind of education system since competition for the best spot is cut-throat. In western education, there is a value of a high level of creativity and students thinking. It is far different from the old Chinese education system, where a student had to learn from there master until they completely understand all that is needed (Ding, 2018, pp. 56).

\section{Examination Orientation}

In the United Kingdom, the essential part of the Chinese education system is their examination score. Most students were reported to be taking their own lives in the case of perceived examination failure, which is so sad (Ding, 2018, pp. 56). Some policymakers illustrate that the education system in China is too narrow while in the western education system, the attention of the teachers guides the students to be more hardworking. The examination has been a significant focus in China's education system since the school performance determines the teaching in the high school syllabus success.

Examination pressure has remained a significant pressure for most of the educators, the parents and even the policymakers. It has led to attempts of law reforms to reduce such demands in China's system of education. According to the China's Ministry of education, (2001), the following changes were proposed; firstly, the education system should leave from centralization to the local relevance and needs, to de-emphasize on 
screening and selective functions. Other changes include moving away from the bookish knowledge and focusing much interest in improving the content of the curriculum. All these changes aim at improving the education system in China.

\section{Students' Engagement in China's Education System}

The intensity of student engagement in learning is the essential influences in China's cultural heritage. In Shanghai classrooms, students are usually engaged and focused on achieving adequate learning outcomes. It is one of the significant achievements which China's education system differs from the western culture where the student engagement may at times are not required. This intense concentration is majorly considered to be one of the significant essential civilizations in the Chinese education system (Finn, 2011, pp. 118). The students learning engagement is not limited to lessons in the Chinese education system. Achieved by consistent homework's given to students, which is a way of governing students life after they move outside the classroom.

\section{Similarities}

A remedial system of the tutorial schools has been implemented in both the Chinese and western education system to improve students' performance through adequate exam preparation. Parents have conclusively accepted the remedial policy, has estimated that $80 \%$ of the parents take their students to tutorial schools. Such parents see the importance of taking their students to such programs with an assumption that this will effectively help their children to pass with flying colours.

Another similarity is the supplementary system, done after school. Such programs allow students to enrol in music classes, fine arts and even martial arts. Both the Chinese and western cultures will enable this program for their students to give them a broader perspective of life. For instance, some students perform better in supplementary programs than in classwork. Both the systems have also had curriculum reforms where natural sciences combine with humanities. Such improvements were made to transform the students from the passive receivers of knowledge into the active learning participants.

In conclusion, drama education in China and the western system's practices are from different perspectives. There are different policies which differentiate the Chinese education system from the Western education system. For instance, the one-child policy in China makes the Chinese children have the responsibility of being their parents and grandparents hope for the future. In China, student's engagement is taken with much importance making it different from the western cultures. It is one of the significant achievements which China's education system differs from the culture of the west where the student engagement may at times not abe required. This intense concentration is majorly considered to be one of the significant vital civilizations in the Chinese education system. Lastly, there also exist different similarities between the Chinese education system and that of the western culture, like proposing law reforms to increase the quality of education provided to students.

\section{References}

Cheng, K. M. (2014). Developing education beyond manpower. In UNDP, Capacity is Development, New York.

Ding, X. (2018), Educational Reform and Development in Shanghai. Paper commissioned by the Shanghai Academy of Education Research for this present study, 5(4), 56-98.

Downing, J. E., \& Paul, H. (2012). Including Students with Severe and Multiple Disabilities in Typical Classrooms. Brookes Publishing Cooperation.

Finn, C. E. (2011). Rethinking Special Education for a New Century. Diane Publishing Company, 13(4), 102-34.

Wickman, R. (2019). Differences in Education between China and Western Countries. China Educational Tours, 6(5), 68-190.

Yongtao, Z. (2015). Essentials of British and American Cultures (Vol. 7, pp. 45-78). Foreign Language Teaching and Research Press.

Youju, L., \& Hazel. (2014). The Higher Education in Cultural View. Zhigong Publishing Company.

\section{Copyrights}

Copyright for this article is retained by the author(s), with first publication rights granted to the journal.

This is an open-access article distributed under the terms and conditions of the Creative Commons Attribution license (http://creativecommons.org/licenses/by/4.0/). 